\title{
Investigation of effects of different cassava cultivars with respect to hydrogen cyanide content on their starch hydrolysis
}

\author{
Eriola BETIKU ${ }^{1 *}$ and Olalekan Saheed ALADE ${ }^{2}$

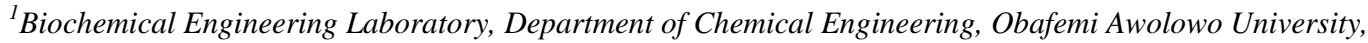 \\ Ile-Ife 220005, Osun State, Nigeria. \\ ${ }^{2}$ Biotechnology Department, Bells University of Technology, Ota, Ogun State, Nigeria. \\ *Corresponding author, E-mail: ebetiku@oauife.edu.ng, Tel: +234-8036602988
}

\begin{abstract}
The effects of Hydrogen Cyanide ( $\mathrm{HCN}$ ) contents of different cultivars of cassava on the kinetic and extent of hydrolysis were studied. The results obtained showed that between 75 and $80 \%$ of HCN content had been lost during processing. Starches from cultivars with different HCN contents, Iditeru White-leaves 70.2 $\mathrm{mg} / \mathrm{kg}$, Iditeru Red-leaves $46.4 \mathrm{mg} / \mathrm{kg}$ and $92005734.6 \mathrm{mg} / \mathrm{kg}$, representing bitter, intermediate and sweet cultivars, respectively, were enzymatically hydrolyzed into reducing sugars. Conversion of starch to reducing sugars reached $246.2 \mathrm{~g} / \mathrm{L}$ for Iditeru white-leaves, $267.9 \mathrm{~g} / \mathrm{L}$ for Iditeru red-leaves and $262.2 \mathrm{~g} / \mathrm{L}$ for 920057 with corresponding Dextrose Equivalent (DE) of 82.1, 89.3 and 87.4\%, respectively. Statistical analysis showed that there was no significant difference $(\mathrm{p}>0.05)$ in the amount of reducing sugars released in the cassava starch hydrolysates (CSH) and the \% DE obtained. After $24 \mathrm{hr}$ of cultivation of Saccharomyces cerevisiae on the CSH as the sole carbon source for the production of baker's yeast on a bench scale bioreactor, the microorganism was able to utilize 80 and $81 \%$ of the sugars present in the CSH of Iditeru-white leaves and 920057 cultivars, respectively. Maximum baker's yeast production of 8.8 and $9.1 \mathrm{~g} / \mathrm{L}$ were obtained for Iditeru-white leaves and 920057 cultivars, respectively. Statistical analysis showed that there was no significant difference $(\mathrm{p}>0.05)$ in the amount of reducing sugars consumed in the CSH as well as the baker's yeast produced. Hence, HCN contents of different cultivars of cassava had no significant effect on both the rate and extent of hydrolysis. Also, the HCN contents did not affect the performance of the microorganism employed in this work.
\end{abstract}

(C) 2011 International Formulae Group. All rights reserved.

Keywords: Cassava, starch, cultivars, hydrogen cyanide, hydrolysis.

\section{INTRODUCTION}

Cassava (Manihot esculenta Crantz), also known as manioc or tapioca (Grace,
1997; Tonukari, 2004; White et al., 1998) is a root crop of tropical and sub-tropical regions of the world, especially Brazil, Nigeria, Zaire

(C) 2011 International Formulae Group. All rights reserved. DOI : http://dx.doi.org/10.4314/ijbcs.v5i6.16 
and Thailand (Aregheore and Agunbiade, 1991). It has been described as a highly efficient producer of carbohydrate mainly in the form of starch (Grace, 1997; White et al., 1998). Although it is regarded as the fourth most important crop in the World after rice, maize and wheat, it is associated with the problem of toxic substances known as linamarin and lotaustralin in ratio (Oke, 2005). The numerous cultivars of cassava are usually grouped in two main categories: Manihot palmate and Manihot aipi, or bitter and sweet cassava, respectively (Grace, 1997; White et al., 1998). This major differentiation is based on the content of hydrocyanic acid $(\mathrm{HCN})$, which causes toxicity in the roots (Grace, 1977; Aregheore and Agunbiade, 1991; RMRDC, 2004). Cassava contains cyanogenic glucosides in the form of linaminrin and to a much less extent, lotaustralin (FAO, 2006). The biosynthesis of these cyanogenic compounds has been extensively reviewed by Oke (2005). Cyanide is synthesized in the leaf and transported to the roots where it is portioned between the peeled and parenchyma (Grace, 1977). The free and bound cyanogenic glycosides (linamirin) are converted to cyanide in the presence of linamarase, a naturally occurring enzyme in cassava. The recognized classification of cassava as sweet variety identifies that the sweet or non-toxic roots contain less than $50 \mathrm{mg} / \mathrm{kg}$ of hydrocyanic acid of fresh matter; and "bitter" ones may produce more than 50 times as much $(1 \mathrm{~g} / \mathrm{kg})$ (Aregheore and Agunbiade, 1991; RMRDC, 2004).

The utilization of cassava roots for both human and animal nutrition appears to be limited by the presence of these cyanogenic glycosides that limit the use of its products and a non-cyanide (acyanophoric) cultivar has not been found (Gomez and Valdivieso, 1985). However, linaminrin is reported to be destroyed during cassava processing: grating, rasping, soaking, drying and cooking at high temperature (White et al., 1998). It has been reported that bitter varieties of cassava contains cyanogenic glucosides, which do not cause serious problem as they are flashed off with the steam during the mash cooking process (Jackson, 1976). Depending on the processing procedure used, the percentage of cyanide reduction varies from 69.85 to $100 \%$ (Kosaric et al., 2001). Furthermore, the tubers are detoxified by hydrolysis of linamirin and lotaustralin by the enzyme linamarase located in the root peels, into $\mathrm{HCN}$, which is volatile and evaporates rapidly at temperature above $28{ }^{\circ} \mathrm{C}$ (RMRDC, 2004). It is also possible to detoxify manioc products by adding sodium thiosulphate, and hence it should be possible to process manioc using other mashing processes (Kreipe, 1982). In a recent study by Oluwole (2008) to determine if cyanogenicity of cassava is associated with geographical area, altitude or level of cyanogenic compounds in garri, a popular cassava food in West Africa, in four geographical areas of Nigeria, it was concluded that cyanogenicity of cassava is determined by environmental factors rather than by conscious selection of cultivars by farmers.

The use of cassava starch hydrolysates in the production of Baker's yeast, ethanol, reducing sugars (e.g. maltose, glucose) is a way of making value-added products of an abundant and renewable resource. Previous work conducted on cassava starch involved kinetic studies on enzymatic hydrolysis of starch from cassava (Paolucci-Jeanjean et al., 2000; Gaouar et al., 1997a; Gorinstein, 1993) conversion of cassava starch into reducing sugars e.g. maltose (Gaouar et al., 1997b) or glucose (Omemu et al., 2005) and bakers' yeast (Ejiofor et al., 1996; Aransiola et al., 2006). However, the effect of hydrogen cyanide content of starches from different cultivars of cassava on their extent of hydrolysis and on the performance of microorganisms has rarely been reported. Therefore, this present work seeks to study the 
effect of $\mathrm{HCN}$ content on the extent of hydrolysis as the amount of reducing sugar released with time from different cultivars of cassava starches. In addition, in order to determine the effect of $\mathrm{HCN}$ on performance of microorganisms, hydrolysates obtained from different cultivars of cassava starches were used as the sole carbon source for the cultivation of Saccharomyces cerevisiae during the production of baker's yeast in a bioreactor under batch conditions.

\section{MATERIALS AND METHODS Materials}

Nine different cultivars of cassava tubers namely: Dolowolojo 53101, IITA 1121, Ege'yan, Congo, Iditeru white-leaves, Iditeru red-leaves, 920057, TME 117 and 4(2)1425 were used for these studies. The first 6 cultivars were obtained from the Obafemi Awolowo University Teaching and Research Farms, Ile-Ife, Osun State, Nigeria while the last set of 3 cultivars were obtained from International Institute of Tropical Agriculture, IITA, Ibadan, Oyo State, Nigeria. Alphaamylase (E.C.3.2.1.1) from bacterium source (Bacillus licheniformis), and glucoamylase (E.C.3.2.1.3) from Aspergillus niger were both obtained from the Federal Institute of Industrial Research, (FIIRO), Oshodi, Lagos, Nigeria. All the chemicals used in this study were of analytical grades.

\section{Cassava processing}

The process of sweet starch extraction (Wheatley and Chuzel, 1993) was employed. The tubers were manually peeled, washed with clean tap water of about $41 / \mathrm{kg}$ fresh tubers and weighed with Metler weighing balance (METTLER PM 30-K). Grating was done by cassava grating machine driven by electric motor. The cassava pulp was sieved (using clean tap water about 3 times the volume of the mash and thoroughly mixed) with a sieve of mesh size $0.033 \mathrm{~cm}$-Teflon cloth. The ungrated chaff was removed and the starch milk obtained was allowed to settle for about 12 hrs. It was decanted and the starch cake obtained was sun-dried on a clean raised concrete-floor for 5 consecutive days with the total drying time of about $48 \mathrm{hrs}$. Drying was stopped when constant weight was observed of the starch granules.

\section{Hydrogen cyanide determination}

The free hydrocyanic acid in both freshly harvested cassava and the dried starch granules were quantitatively determined by alkaline titration method (Grace, 1977). Starch slurry, $5 \%(\mathrm{w} / \mathrm{v})$ was prepared by soaking 10 $\mathrm{g}$ of the crushed dried starch granules in 200 $\mathrm{ml}$ distilled water for $4 \mathrm{~h}$ in a distillation flask. The solution was steam distilled into $20 \mathrm{ml}$ of $0.625 \mathrm{M} \mathrm{NaOH}$ solution until about $150 \mathrm{ml}$ of the distillate was obtained. The distillate was diluted to $250 \mathrm{ml}$ volume with distilled water. Eight milliliters of $5 \%$ potassium iodide solution was added to $100 \mathrm{ml}$ of the diluted solution and was titrated against $0.02 \mathrm{~N}$ silver nitrate solution. The end-point was indicated by a light-yellow colouration. The hydrogen cyanide (mg) in the sample was estimated by multiplying the volume of $0.02 \mathrm{~N}$ silver nitrate used by 1.08 .

\section{Hydrolysis and kinetics experiments}

The starches from three cultivars of cassava (920057, Iditeru white-leaves and Iditeru red-leaves) were selected for this study. Enzymatic hydrolysis was performed as described by Chaplin and Bucke (1990). The starch was slurried (300 g/l) with cold water at room temperature in a $250 \mathrm{ml}$ conical flask. The $\mathrm{pH}$ values of the starch slurries were taken after which $50 \mathrm{ppm}$ of $\mathrm{Ca}^{2+}$ was added to the slurries to stabilize the enzyme activity at the processing temperature. The $\mathrm{pH}$ was adjusted to 6.5 using citrate-phosphate buffer. The starch was gelatinized at temperature of $80-90{ }^{\circ} \mathrm{C}$ for $5 \mathrm{~min}$ with continuous stirring. Alpha-amylase was added at this temperature (2 ml enzyme/100 ml slurry). The slurries 
were incubated in an environment controlled rotary incubator shaker at $95{ }^{\circ} \mathrm{C}$ and $450 \mathrm{rpm}$ for 2.5 hrs. Kinetics was followed by withdrawing samples at interval of $30 \mathrm{~min}$ for this liquefaction stage. The liquefied starches were allowed to cool to temperature of $60{ }^{\circ} \mathrm{C}$; the $\mathrm{pH}$ values were adjusted to 4.5 and were subsequently saccharified with glucoamylase ( $2 \mathrm{ml}$ enzyme/100 $\mathrm{ml}$ slurry) incubated at 60 ${ }^{\circ} \mathrm{C}, \quad 450 \mathrm{rpm}$ for $72 \mathrm{hrs}$. Samples were withdrawn at intervals of $12 \mathrm{~h}$ to follow the kinetics. This experiment was done in duplicates.

\section{Baker's Yeast production \\ Preparation of inoculum}

Fifty milliliters of a mineral salts solution, which is a modification of the synthetic medium developed by O'Connor et al. (1992) was measured into $100 \mathrm{ml}$ Erlenmeyer flasks. The flasks were cotton plugged and autoclaved at $121{ }^{\circ} \mathrm{C}$ for $15 \mathrm{~min}$. The sterilized medium was allowed to cool to ambient temperature and large amount of the S. cerevisiae (obtained from Department of Microbiology, Obafemi Awolowo University, Ile-Ife) was scraped from the cultured slant and added to each of the medium in the flasks aseptically. The flasks were transferred to the gyratory incubator shaker and growth was achieved at temperature of $30{ }^{\circ} \mathrm{C}$ and agitation of $200 \mathrm{rpm}$ after incubation for $18 \mathrm{hrs}$.

\section{Fermentation}

Two aerobic cultivations were carried out on a bench scale bioreactor (New Brunswick Co., USA) with the initial sugar concentrations of $3.8 \mathrm{~g} / \mathrm{l}$ (for 920057 cultivar) and $4.8 \mathrm{~g} / \mathrm{l}$ (for Iditeru-white leaves cultivar). Prior to inoculation in each run, the fermentor vessel containing 21 of the medium and 0.51 of the mineral constituents were sterilized by autoclaving at $121{ }^{\circ} \mathrm{C}$ for 15 minutes. The vessel was allowed to cool and coupled back to the fermentor assembly. Inoculum $(7.5 \mathrm{ml}$ inoculum/100 $\mathrm{ml}$ fermentation medium) was then introduced into the fermentor vessel aseptically and one milliliter of antifoam was also added. The culture was agitated at 200 rpm with an airflow rate of 2 vvm. Cultivation was conducted at $30{ }^{\circ} \mathrm{C}$ and $\mathrm{pH}$ of 4.5 . Samples were taken at $6 \mathrm{hrs}$ interval. Each of the samples collected was centrifuged and the supernatant was analyzed for reducing sugar concentration. The residue at the bottom was used for biomass concentration.

\section{Reducing sugar concentration analysis}

The Miller's DNS method (Miller, 1959) and modified DNS Reagent (Mwesigye, 1988) was employed in other to estimate the reducing sugar content of the hydrolysate with time. The Dextrose Equivalent expressed as percentage (or percentage substrate conversion) was calculated as described in the following equation.

$\% D E=\frac{\text { Reducing sugar expressed as glucose }(\mathrm{g} / \mathrm{l})}{\text { Total Carbohydrate }(\mathrm{g} / \mathrm{l})}$

\section{Biomass concentration}

For each run $50 \mathrm{ml}$ of samples was collected at regular interval into pre-weighed tube, which was then centrifuged at 10,000 rpm for $10 \mathrm{~min}$. The pellets were dried to constant weight in an oven at $80{ }^{\circ} \mathrm{C}$, allowed to cool in a desiccators and the final weight was recorded.

\section{Statistical analysis}

One - way ANOVA (at 5\% level of significance) was performed with Origin 6.1 statistical software.

\section{RESULTS}

Table 1 shows the hydrogen cyanide (HCN) contents of the different cassava cultivars studied. The HCN contents of the processed starches from the first six cultivars were determined while both the freshly harvested tubers and processed starches of the last three cultivars were measured. The results showed that between 75 and $80 \%$ of $\mathrm{HCN}$ 
content had been lost via processing. The time course of hydrolysis of the three cultivars of cassava starch (920057, Iditeru-white leaves and Iditeru red-leaves, representing sweet, bitter and intermediate cultivars, respectively) are presented in Figure 1 (with starting starch concentration of $300 \mathrm{~g} / \mathrm{l}$ ). After about $70 \mathrm{hrs}$ of hydrolysis, conversion of starch to reducing sugar reached $246.2 \mathrm{~g} / \mathrm{l}$ for Iditeru whiteleaves, $267.9 \mathrm{~g} / \mathrm{l}$ for Iditeru red-leaves and $262.2 \mathrm{~g} / 1$ for 920057 with corresponding Dextrose Equivalent (DE) of 82.1, 89.3 and $87.4 \%$, respectively. One-way ANOVA statistical analysis showed that there was no significant difference $(p>0.05)$ in the amount of reducing sugar released in the starch hydrolysates as well as the \%DE during the course of hydrolysis of starches from the different cultivars studied.

The hydrolysates obtained from the hydrolysis of both Iditeru white-leaves and 920057 cultivars were employed as the sole carbon source for the cultivation of $S$. cerevisiae in a bench scale bioreactor under batch conditions. Results obtained are depicted in Figures 2 and 3. The cassava starch hydrolysates from the two cultivars were able to support growth of the $S$. cerevisiae. After $24 \mathrm{~h}$ of cultivation, the yeast was able to utilize 80 and $81 \%$ of the sugar present in the hydrolysates of Iditeru-white leaves and 920057 cultivars, respectively. Maximum baker's yeast production of 8.8 and $9.1 \mathrm{~g} / 1$ were obtained for Iditeru-white leaves and 920057 cultivars, respectively. One-way ANOVA statistical analysis showed that there was no significant difference $(p>0.05)$ in the amount of reducing sugar consumed in the starch hydrolysates as well as the baker's yeast produced in both cultivars employed in this work. The fact that there was no significant difference in the results obtained may be attributed to the sterilization of the hydrolysates at $121{ }^{\circ} \mathrm{C}$ for $15 \mathrm{~min}$ before the commencement of fermentation in the bioreactor. It may be that the hydrogen cyanide contents have been flashed off at this point.

Table 1: Hydrogen cyanide content in cassava cultivars and processed starches.

\begin{tabular}{lcc}
\hline Cassava Cultivars & $\begin{array}{l}\text { HCN content of freshly harvested } \\
\text { cassava tubers }\end{array}$ (mg/kg) & $\begin{array}{l}\text { HCN content after starch } \\
\text { processing }(\mathbf{m g} / \mathbf{k g})\end{array}$ \\
\hline Iditeru red-leaves & $\mathrm{ND}$ & 46.44 \\
Iditeru white-leaves & $\mathrm{ND}$ & 70.20 \\
IITA 1/1206 & $\mathrm{ND}$ & 66.60 \\
Dolowolojo 53101 & $\mathrm{ND}$ & 56.92 \\
Odogbo & $\mathrm{ND}$ & 65.88 \\
Congo & $\mathrm{ND}$ & 62.24 \\
920057 & 136.08 & 34.56 \\
TME 117 & 75.60 & 17.28 \\
4(2)1425 & 108.00 & 21.60 \\
\hline
\end{tabular}

ND - values not determined from the freshly harvested cassava tubers. 


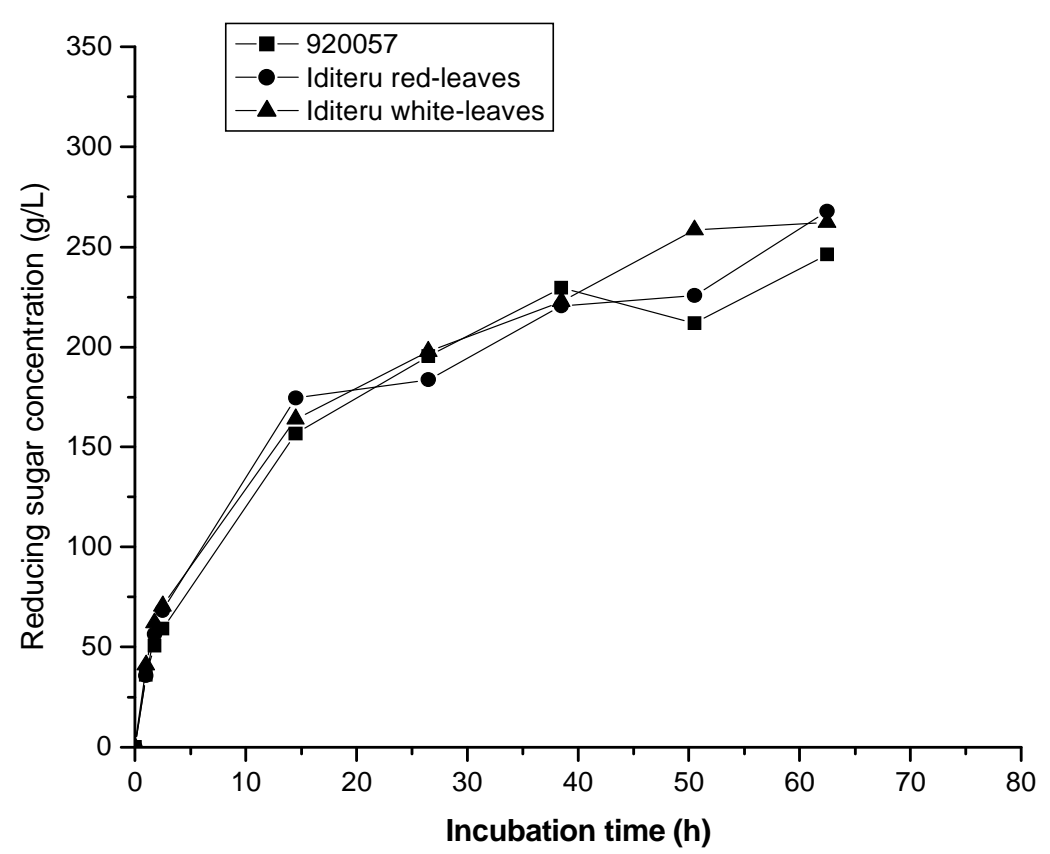

Figure 1: Plot of reducing sugar concentration (g/l) against incubation time (h) for 920057, Iditeru white-leaves and Iditeru red-leaves.

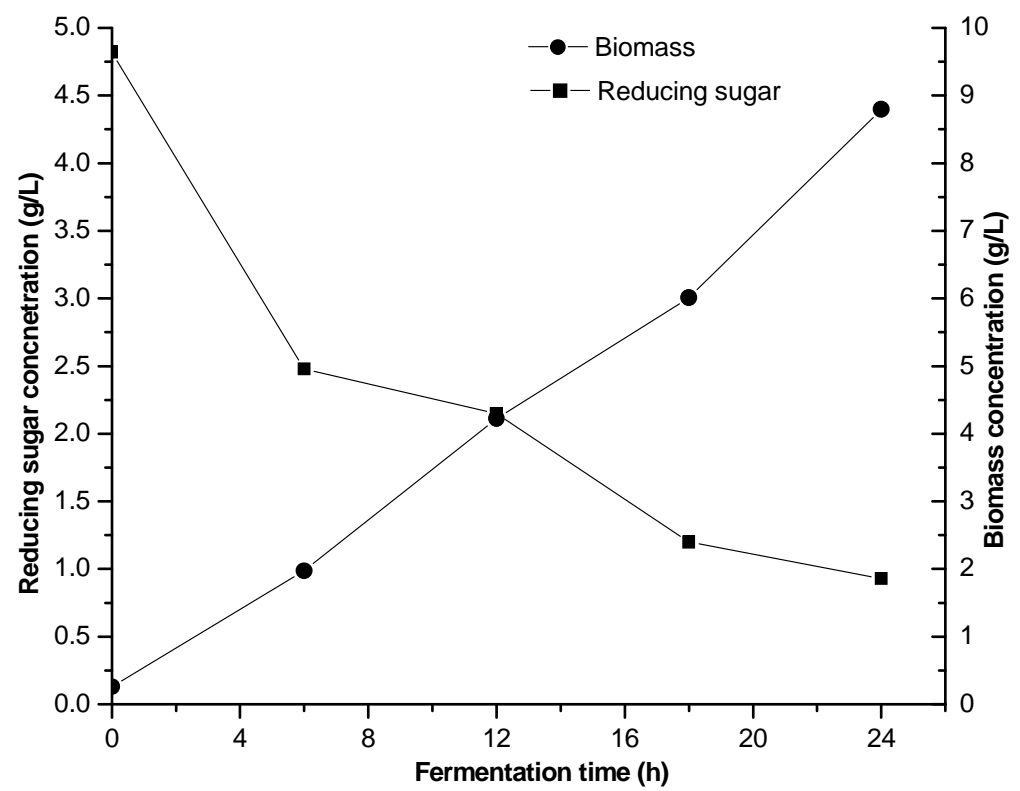

Figure 2: Plot of reducing sugar concentration (g/l) and biomass concentration (g/l) against fermentation time (h) for Iditeru-white leaves cultivar $(70.20 \mathrm{mg} / \mathrm{kg} \mathrm{HCN}$ content). 


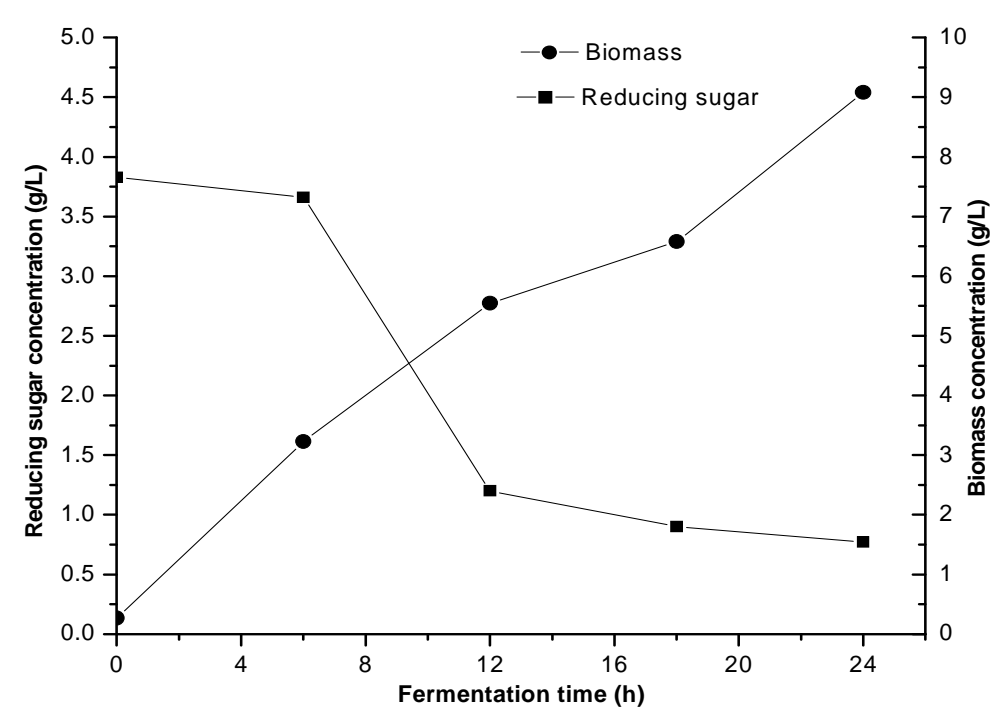

Figure 3: Plot of reducing sugar concentration $(\mathrm{g} / \mathrm{l})$ and biomass concentration $(\mathrm{g} / \mathrm{l})$ against fermentation time (h) for 920057 cultivar ( $34.56 \mathrm{mg} / \mathrm{kg} \mathrm{HCN}$ content).

\section{DISCUSSION}

This study was embarked upon to determine the effects of $\mathrm{HCN}$ contents of different cultivars of cassava on the extent of hydrolysis of their starches and on the performance of microorganisms in utilization of the hydrolysates obtained as the sole carbon source for the cultivation of Saccharomyces cerevisiae during the production of baker's yeast in a Bioreactor. This was with a view to adding value to cassava, an abundant and renewable resource.

Reductions of HCN contents observed in this study are corroborated by past reports in which the quantities present in different cultivars of cassava were substantially reduced in the course of starch processing. Many investigations on the hydrogen cyanide content of different cultivars of cassava support this suggestion. El Tinay et al. (1984) reported $80-87 \%$ loss of cyanide after 8 days of fermentation in the traditional method and 51- 53\% after 4 days with whole unpeeled tubers while in the sweet varieties, the cyanide loss in the whole tuber was not significant after 5 days. On the other hand, $83-91 \%$ loss in cyanide was observed in the peeled and crushed tubers when water was added. Also, Arihantana and Buckle (1986) studied cassava detoxification during traditional fermentation process and reported total cyanide loss of $58-$ 87\%. Gomez and Valdivieso (1985) investigated the effect of sun-drying on concrete floor and oven drying on trays on the elimination of cyanide from cassava whole root chips. According to their findings, sundrying eliminated $86-94 \%$ of the initial total cyanide and $93-98 \%$ of the bound cyanide, whereas the reduction was found to be 77 $80 \%$ and $81-85 \%$ for oven drying at $60{ }^{\circ} \mathrm{C}$, respectively. In a similar study by Gomez et al. (1984), $60-80 \%$ free form of cyanide was observed in the tuber with sun and oven drying methods. Furthermore, Vascozelos et al. (1990) concluded that important stages that lead to cyanide elimination in "garri" processing are the initial grating of the tubers and final stage of roasting.

The fact that there was no significant difference in the amount of reducing sugar released in the starch hydrolysates as well as 
the \%DE during the course of hydrolysis of starches from the different cultivars studied suggests that $\mathrm{HCN}$ present in the processed starches may have been further flashed off during the hydrolysis process, which involved high temperatures. It has been earlier reported (RMRDC, 2004) that $\mathrm{HCN}$ is volatile and evaporates rapidly at temperature above 28 ${ }^{\circ} \mathrm{C}$.

\section{Conclusion}

This work established that the hydrogen cyanide contents of different cultivars of cassava have no significant influence on the hydrolysis of starches extracted from them. It was also observed that the processing of the cultivars employed in this study led to significant reduction in the hydrogen cyanide contents (75-80\%). Hydrolysates obtained from the cultivars were able to serve as the sole carbon source for the cultivation of the yeast (S. cerevisiae). No significant difference was noticed in utilization of the sugars in the hydrolysates as well as in the production of baker's yeast by the organism. Hence, hydrogen cyanide contents of different cultivars of cassava had no significant effect on both the kinetics and extent of hydrolysis. In addition, the hydrogen cyanide contents did not affect the performance of the organism employed in this work.

\section{ACKNOWLEDGEMENTS}

Authors acknowledged the technical assistance offered by Messers Oyawale Mayowa, Omowo Damilola and Adebayo Akeem. Equipment donations to Dr. Betiku by the World University Service, Germany is gratefully acknowledged.

\section{REFERENCES}

Aransiola EF, Betiku E, Layokun SK, Solomon BO. 2006. Production of baker's yeast from cassava starch hydrolyzates in a bioreactor under batch process. JNSChE, 21: 106-113.
Aregheore EM, Agunbiade OO. 1991. The toxic effects of cassava (Manihot esculenta Crantz) diets on humans: a review. Veterinary and Human Toxicology, 33(3): 274-275.

Arihantana MB, Buckle KA. 1986. Effect of non-enzymatic browning of starch and sugars on total cyanide determination in cassava by an enzymic assay. Journal of Food Technology, 21: 189-197.

Chaplin M, Bucke C. 1990. Enzyme Technology, Cambridge University Press, (http://www.lsbu.ac.uk/biology/enztech/).

Ejiofor AO, Chisti Y, Moo-Young M. 1996. Culture of Saccharomyces cerevisiae on hydrolyzed waste cassava starch for production of baking-quality yeast. Enzyme Microbial Technology, 18: 519525.

El Tinay AH, Bureng PL, Yas EAE. 1984. Hydrocyanic acid levels in fermented cassava. Journal of Food Technology, 19: 197-202.

FAO (Food and Agriculture Organization of the United Nations). 2006. Starch market adds value to cassava. Agriculture and Consumer Protection Department, FAO (http://www.fao.org).

Gaouar O, Aymard C, Zakhia N, Rios GM. 1997a. Kinetic studies on the hydrolysis of soluble and cassava starches by maltogenase. Starch, 49(6): 231-237.

Gaouar O, Aymard C, Zakhia N, Rios GM. 1997b. Enzymatic hydrolysis of cassava starch into maltose syrup in a continuous membrane reactor. Journal Chemical Technology and Biotechnology, 69(3): 367-375.

Gomez G, Valdivieso M, Delacuesta D, Kawano K. 1984. Cyanide content in the whole - root chips of ten cassava cultivars and its reduction by oven-drying or sun-drying on trays, Journal of Food Technology, 19: 97-102.

Gomez G, Valdivieso M. 1985. Effect of drying temperature and loading rates on cyanide elimination from cassava whole- 
root chips. Journal of Food Technology, 20: $375-382$.

Grace MR. 1977. Cassava processing, FAO Plant Production and Protection Series, No.3http://www.fao.org/docrep/X5032E0 0.htm).

Gorinstein S. 1993. Kinetic studies during enzyme hydrolysis of potato and cassava starch. Starch, 45:91-95.

Jackson EA. 1976. Brazil's national alcohol Programme. Process Biochemistry, 11(5): 29-36.

Kosaric N, Vardar-Sukan F, Pieper HJ. 2001. The Biotechnology of Ethanol: Classical and Future Applications, Roehr (ed.). M Wiley-VCH GmH: Weinheim.

Kreipe H. 1982. Der drucklose StarkeaufschluB in Theorie und Praxis, Handbuck. Brennerei Alkoholwirtsch, 29; 204-212.

Miller GL. 1959. Use of dinitrosalicyclic acid reagent for determination of reducing sugar. Biotechnology and Bioengineering Symposium, 5: 193-219.

Mwesigye PK. 1988. Enzymatic hydrolysis of lignocelluloses materials (sawdust). M.Sc. Thesis, Obafemi Awolowo University, Ile-Ife, Nigeria.

O'Connor GM, Sanchez-Riers F, Coone CL. 1992. Design and evaluation of control strategies for high cell density fermentations. Biotechnology and Bioengineering, 39:293-304.

Ogunsua AO. 1989. Total cyanide levels in bread made from wheat and cassava composite flours. International Journal of Food Science and Technology, 24: 361365.

Oke OL. 2005. Cassava: Yesterday, Today and Tomorrow. Ife Lecture Series No. 7.
The Postgraduate College, Obafemi Awolowo University, Ile-Ife, Nigeria.

Oluwole SA. 2008. Cyanogenicity of cassava varieties and risk of exposure to cyanide from cassava food in Nigerian communities. Journal of the Science of Food and Agriculture, 88(6): 962 - 969.

Omemu AM, Akpan I, Bankole MO, Teniola OD. 2005. Hydrolysis of raw tuber starches by amylase of Aspergillus niger AM07 isolated from the soil. African Journal of Biotechnology, 4: 19-25.

Paolucci-Jeanjean D, Belleville MP, Zakhia N, Rios GM. 2000. Kinetics of cassava starch hydrolysis with termamyl enzyme. Biotechnology and Bioengineering, 68 : 71-77.

RMRDC, Raw Materials Research and Development Council Federal Ministry of Science and Technology. Abuja - Report on Survey of Agro Raw Materials in Nigeria - Cassava, Maiden Edition, 2004.

Tonukari NJ. 2004. Cassava and the future of starch. Electronic Journal of Biotechnology, 7: 5-8.

Vascozelos AT, Twiddy DR, Westby A, Keilly PJA. 1990. Detoxification of cassava during gari preparation. International Journal of Food Science and Technology, 25: 198-203.

Wheatley CC, Chuzel G. 1993. Cassava. In Encyclopedia of Food Technology and Nutrition, Macrae R, Robison RK, Sadler MJ (eds). Academic Press Inc.: London; 734- 742.

White WLB, Arias-Garzon DI, McMahon JM, Sayre RT. 1998. Cyanogenesis in Cassava - the role of hydroxynitrile lyase in root cyanide production. Plant Physiology, 116: 1219-1225. 